\title{
Erratum to: Long-term monitoring of opioid, sedative and anti-inflammatory drugs in horse hair using a selective and sensitive LC-MS/MS procedure
}

Milena M. Madry ${ }^{1 *}$, Barbara S. Spycher ${ }^{2}$, Jacqueline Kupper ${ }^{3}$, Anton Fuerst $^{4}$, Markus R. Baumgartner ${ }^{1}$, Thomas Kraemer ${ }^{2}$ and Hanspeter Naegeli ${ }^{3^{*}}$

\section{Erratum}

Unfortunately, after publication of this article [1], it was noticed that the axis numbering of Fig. 4 was switched. The numbering of the $x$-axis should be on the $y$-axis and vice versa. The corrected figure can be seen below.

\begin{abstract}
Author details
${ }^{1}$ Zurich Institute of Forensic Medicine, Center for Forensic Hair Analytics, University of Zurich, Zurich, Switzerland. ${ }^{2}$ Zurich Institute of Forensic Medicine, Center for Forensic Pharmacology and Toxicology, University of Zurich, Zurich, Switzerland. ${ }^{3}$ Institute of Veterinary Pharmacology and Toxicology, University of Zurich, Zurich, Switzerland. ${ }^{4}$ Clinic of Veterinary Surgery, Department of Large Animal Surgery, University of Zurich, Zurich, Switzerland.
\end{abstract}

Received: 15 June 2016 Accepted: 15 June 2016

Published online: 22 June 2016

\section{Reference}

1. Madry MM, Spycher BS, Kupper J, Fuerst A, Baumgartner MR, Kraemer T, et al. Long-term monitoring of opioid sedative and anti-inflammatory drugs in horse hair using a selective and sensitive LC-MS/MS procedure. BMC Vet Res. 2016;12:84. doi:10.1186/s12917-016-0709-5.

\footnotetext{
* Correspondence: milena.madry@irm.uzh.ch; hanspeter.naegeli@vetpharm. uzh.ch

'Zurich Institute of Forensic Medicine, Center for Forensic Hair Analytics, University of Zurich, Zurich, Switzerland

${ }^{3}$ Institute of Veterinary Pharmacology and Toxicology, University of Zurich, Zurich, Switzerland

Full list of author information is available at the end of the article
}

Submit your next manuscript to BioMed Central and we will help you at every step:

- We accept pre-submission inquiries

- Our selector tool helps you to find the most relevant journal

- We provide round the clock customer support

- Convenient online submission

- Thorough peer review

- Inclusion in PubMed and all major indexing services

- Maximum visibility for your research

Submit your manuscript at www.biomedcentral.com/submit 


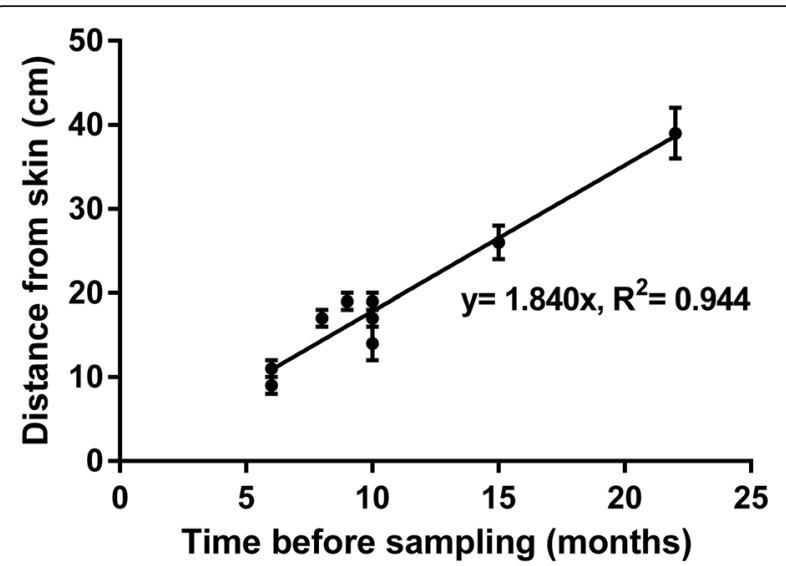

Fig. 4 Drug localization in horse hair as a function of the time of documented drug administrations. This graph shows the median distance from skin and range of segments with clearly increased drug incorporation. The slop of the resulting linear relationship is consistent with an average growth rate of $1.84 \mathrm{~cm}$ per month 